\title{
ANTIBACTERIAL ACTIVITY TEST OF LEAVES KECOMBRANG (NICOLAIA SPECIOSA) ETHANOLIC EXTRACTS AGAINST STAPHYLOCOCCUS AUREUS
}

\section{UJI AKTIVITAS ANTIBAKTERI EKSTRAK ETANOLIK DAUN KECOMBRANG (NICOLAIA SPECIOSA) TERHADAP STAPHYLOCOCCUS AUREUS}

\author{
Rinda Binugraheni ${ }^{1^{*}}$, Ndaru Trisni Larasati ${ }^{2}$
}

\begin{abstract}
Infectious diseases that often occur in humans are skin infections. One of the bacteria that cause infection in humans is Staphylococcus aureus. One of the plants used as an ingredient in traditional medicine and used as an anti-bacterial is a kecombrang plant. This research aims to test the antibacterial activity of leaf extract of kecombrang against Staphylococcus aureus. Kecombrang leaf obtained from Pandeglang Banten. Kecombrang leaves extracted with a maceration method using $96 \%$ ethanol solvent. Extracts of leaves are made in a various concentrations $(100 \%, 75 \%, 50 \%$, and $25 \%)$. The antibacterial activity test was performed by using the diffusion method to find out the large zone of diameter are formed to inhibiting Staphylococcus aureus bacteria.The results of the antibacterial activity of the leaves extract of kecombrang to Staphylococcus aureus at 25\%,50\%,75\% and $100 \%$ concentrations respectively were $12.67 \mathrm{~mm}$, $14.33 \mathrm{~mm}, 15.33 \mathrm{~mm}$, and $17.00 \mathrm{~mm}$. The data result showed, that leaf extract of kecombrang with $100 \%$ concentration had the largest inhibiting zone diameter of $17.00 \mathrm{~mm}$, among other concentrations. This suggests that kecombrang leaf extract have antibacterial activity against Staphylococcus aureus.
\end{abstract}

Keywords: Kecombrang, Antibacteria, Staphylococcus Aureus.

\section{INTISARI}

Penyakit infeksi yang sering terjadi pada manusia adalah infeksi kulit. Salah satu bakteri penyebab infeksi pada manusia adalah bakteri Staphylococcus aureus. Salah satu tanaman yang banyak dimanfaatkan sebagai bahan obat tradisional dan sebagai antibakteri adalah tanaman Kecombrang. Penelitian ini bertujuan untuk menguji aktivitas antibakteri ekstrak daun kecombrang terhadap Staphylococcus aureus. Daun kecombrang diperoleh dari Pandeglang Banten. Daun Kecombrang diekstrak dengan metode maserasi menggunakan pelarut etanol $96 \%$. Ekstrak daun dibuat dalam berbagai variasi konsentrasi (100\%, 75\%, 50\%, dan 25\%). Uji aktivitas antibakteri dilakukan dengan menggunakan metode difusi untuk

\section{Afiliasi Penulis}

D3 Analis Kesehatan Universitas Setia Budi

\section{Korespondensi kepada}

R. Binugraheni rinda.binugraheni@gmail.com mengetahui besar diameter zona yang terbentuk untuk menghambat bakteri Staphylococcus aureus. Hasil penelitian aktivitas antibakteri dari ekstrak daun kecombrang terhadap Staphylococcus aureus pada konsentrasi $25 \%, 50 \%$, 75\% dan $100 \%$ secara berturut adalah $12,67 \mathrm{~mm}, 14,33 \mathrm{~mm}, 15,33 \mathrm{~mm}$, dan 17,00. Data hasil menunjukan bahwa ekstrak daun kecombrang dengan konsentrasi $100 \%$ memiliki diameter zona 
hambat paling besar yaitu $17.00 \mathrm{~mm}$, diantara konsentrasi yang lain. Hal ini menunjukan ekstrak daun kecombrang mempunyai aktivitas anti bakteri terhadap Staphylococcus aureus.

Kata kunci: Kecombrang, Antibakteri, Staphylococcus Aureus

\section{PENDAHULUAN}

Indonesia merupakan salah satu negara berkembang dengan iklim tropis. Hal ini mempengaruhi tingkat penyakit infeksi yang terjadi di Indonesia. Prevalensi penyakit infeksi pada beberapa dekade terakhir terus mengalami peningkatan yaitu mencapai angka 23,5\% pada tahun 2006 (Sulistyaningsih, 2010). Pada Negara berkembang masih sangat rentan mengalami penyakit infeksi kulit dengan jumlah prevalensi berkisar antara $20-80 \%$ per tahun. Salah satu bakteri penyebab infeksi pada manusia adalah bakteri Staphylococcus aureus. Infeksi Staphylococcus aureus yang terjadi dapat di kontrol dengan penggunaan zat antibiotik yang mengandung antibakteri. Namun penggunaan antibiotik kimiawi memiliki efek samping apabila dikonsumsi secara terus menerus, yaitu efek samping berupa efek toksik, alergi, atau biologis serta dapat menyebabkan resistensi terhadap bakteri penyebab penyakit (Amin, 2014).

Tanaman obat yang melimpah di Indonesia adalah Kecombrang (Nicolaia speciosa). Kecombrang merupakan salah satu jenis rempah rempah golongan Zingiberaceae. Tanaman kecombrang sudah sejak lama dikenal dan dimanfaatkan oleh masyarakat sebagai obat tradisional penyakit kanker, dan tumor. Beberapa penelitian menunjukan bunga dan daun kecombrang memiliki aktivitas antibakteri terhadap bakteri gram positif maupun gram negatif (Kusumawati et al., 2015). Naufalin et al (2005) melaporkan bahwa polaritas ekstrak bunga kecombrang mempengaruhi aktivitas antibakteri, dimana ekstrak etil asetat menunjukan aktivitas lebih tinggi dari pada ekstrak etanol terhadap Staphylococcus aeureus.

Menurut Kusumawati et al., (2015) terdapat beberapa zat yang terkandung di dalam daun kecombrang, antara lain saponin, flavonoid, alkaloid dan tannin yang dapat menghambat pertumbuhan Salmonella typhi. Sedangkan menurut penelitian yang telah dilakukan oleh Ningtyas (2010) ekstrak air daun kecombrang memiliki kemampuan antibakteri dan antioksidan yang dapat menghambat pertumbuhan Escherichia coli, Staphylococcus aureus. Menurut Koraag et al., (2016) daun dan bunga kecombrang juga berkhasiat sebagai larvasida. Penelitian mengenai tanaman kecombrang sudah banyak dilakukan namun yang terfokus pada daun kecombrang sebagai antibakteri masih sedikit, oleh sebab itu perlu dilakukan penelitian lebih jauh mengenai daun kecombrang (Nicolaia speciosa) sebagai bahan antibakteri. Pada penelitian ini akan dilakukan uji aktivitas antibakteri dari ekstrak etanol daun kecombrang menggunakan metode difusi. Hal ini dilakukan untuk meneliti manfaat lebih luas dari daun kecombrang terhadap bakteri Staphylococcus aureus sebagai antibakteri.

\section{METODE}

Penelitian ini dilaksanakan pada bulan Desember - April 2018 yang bertempat di Laboratorium Mikrobiologi dan Fitokimia Universitas Setia Budi, Surakarta.

Alat

Alat yang digunakan pada penelitian ini adalah ayakan 40 mesh, oven, Bidwell 
Sterling, klem, statif, rotary evaporator, neraca analitik, cawan petri steril, inkas, tabung reaksi steril, jarum oshe, object glass, pebakar spirtus, inkubator, autoclave, kapas lidi steril, mikroskop.

\section{Bahan}

Bahan yang digunakan pada penelitian ini adalah ekstrak etanol daun kecombrang, Medium Brain Heart Infusion (BHI), media Vogel Johnson Agar (VJA), dan media Muller Hilton Agar (MHA), kalium telurit, larutan $\mathrm{H} 2 \mathrm{O} 23 \%$, plasmacitrat, xylen, etanol $96 \%$, DMSO $2 \%$, spirtus, minyak imersi, cat Gram A (kristal violet), Gram B (lugol iodine), Gram C (alkohol-aceton), Gram D (safranin), Standar Mc Farland 0,5, Kloramfenikol.

\section{Prosedur penelitian}

1. Pembuatan Ekstrak Etanolik Daun Kecombrang

Proses ekstraksi dilakukan dengan metode maserasi yaitu simplisia serbuk daun kecombrang sebanyak200 gramdimasukkan ke dalam botol berwarna gelap dan ditambahkan 2 liter etanol 96\%. Serbuk direndam selama 3 hari dan dilakukan pengojokan sebanyak 3-4 kali sehari. Ekstrak yang diperoleh disaring menggunakan alat penyaring yang dilapisi flannel. Filtrat yang didapat dipisahkan dari pelarutnya dengan cara diuapkan menggunakanvacum rotatory evaporator kemudian dipekatkan di dalam oven selama 72 jam sehingga didapatkan ekstrak pekat.

2. Uji Fitokimia Ekstrak Etanolik Daun Kecombrang

Golongan senyawa yang diuji pada ekstrak daun kecombrang meliputi flavonoid, saponin, dan tanin.

a. Identifikasi Flavonoid Identifikasi flavonoid dilakukan dengan cara ekstrak daun kecombrang sebanyak $5 \mathrm{ml}$ dimasukkan ke dalam tabung reaksi, ditambahkan 5 tetes $\mathrm{HCl}$ pekat, sedikit serbuk $\mathrm{Mg}$ dan 5 tetes amil alkohol kemudian dikocok. Bila terbentuk warna merah, jingga, atau kuning menunjukkan adanya flavonoid.

b. Identifikasi Saponin

Uji saponin dilakukan dengan cara ekstrak daun kecombrang sebanyak $5 \mathrm{ml}$ dimasukkan kedalam tabung, kemudian ditambahkan $5 \mathrm{ml}$ air panas dan dikocok selama 15 menit, lalu ditambahkan 1 sampai 2 tetes $\mathrm{HCl} 2 \mathrm{~N}$. Jika terbentuk busa permanen menunjukkan adanya saponin.

c. Identifikasi Tanin

Uji tanin dilakukan dengan ekstrak daun kecombrang sebanyak $5 \mathrm{ml}$ dimasukkan ke dalam tabung reaksi, kemudian ditambahkan 1 sampai 2 tetes larutan $\mathrm{Fe}(\mathrm{Cl})_{3} \quad 1 \%$. Bila terbentuk warna biru tua dan hijau kehitaman, menunjukkan adanya tanin.

3. Uji Aktivitas Antibakteri

Uji aktivitas antibakteri dilakukan dengan metode difusi (sumuran) yang ditandai terbentuknya zona hambat yang terbentuk disekitar sumuran. Uji ini dilakukan dengan carasuspensi bakteri Staphylococcus aureus digoreskan dengan kapas lidi steril pada media MHA lalu didiamkan selama 10 menit. Media MHA tersebut dilubangi sebanyak 6 sumuran menggunakan boorprof. Setiap sumuran masing-masing di isi dengan $50 \mu \mathrm{l}$ kloramfenikol sebagai kontrol positif, DMSO $2 \%$ sebagai kontrol negatif, ekstrak yang diuji dengan konsentrasi 25\%, 50\%, $75 \%$, 100\%. Kemudian diinkubasi pada suhu $37^{\circ} \mathrm{C}$ selama 24 jam. Diamati dan diukur zona hambat yang terbentuk. 
4. Analisis Data

Data yang diperoleh dianalisis menggunakan uji One Way Anova (analisa varian satu arah) untuk mengetahui adanya perbedaan antara masing-masing konsentrasi ekstrak daun kecombrang yang menghambat pertumbuhan bakteri Staphylococcus aureus dan uji Post Hoc (SNK) untuk menentukan adanya perbedaan pada masing-masing konsentrasi daun kecombrang.

\section{HASIL DAN PEMBAHASAN}

\section{Hasil Ekstraksi Daun Kecombrang}

Ekstrak sebanyak 200gram direndam dalam $2000 \mathrm{ml}$ etanol 96\%. Pembuatan ekstrak daun kecombrang dilakukan menggunakan metode maserasi. Ekstrak hasil maserasi didapatkan sebanyak $500 \mathrm{ml}$ dengan konsistensi ekstrak yang pekat dan menggumpal. Metode maserasi merupakan penyarian yang sederhana dan mudah. Cairan penyari akan menembus dinding sel dan masuk ke rongga sel yang mengandung zat aktif sehingga zat aktif akan larut karena karena perbedaan konsentrasi antara larutan larutan zat aktif di dalam sel dengan yang di luar sel, maka larutan yang terpekat didesak keluar. Selain itu faktor kerusakan zat aktif lebih kecil karena pada metode ini tidak menggunakan panas yang mungkin dapat merusak zat aktif yang ditarik (Kusumawati, et al., 2015). Pelarut yang dipakai pada proses ekstraksi adalah etanol 96\%. Etanol 96\% dipilih karena tidak toksik dan senyawa flavonoid, tannin, saponin larut dalam pelarut polar (Handoko, 1995).

\section{Hasil Uji Fitokimia}

Berasarkan uji fitokimia ekstrak etanolik daun kecombrang, diperoleh hasil sebagai berikut:

Tabel 1 | Hasil uji fitokimia ekstrak etanolik daun kecombrang

\begin{tabular}{lllc}
\hline \multicolumn{1}{c}{ Uji } & \multicolumn{1}{c}{ Pereaksi } & \multicolumn{1}{c}{ Hasil } & Keterangan \\
\hline Flavonoid & $\begin{array}{l}\mathrm{HCl} \text { pekat }+ \\
\text { serbuk } \mathrm{Mg}+\text { Amil } \\
\text { Alkohol. }\end{array}$ & $\begin{array}{l}\text { Terbentuk warna merah, } \\
\text { Kuning, Jingga }\end{array}$ & + \\
\hline Saponin & $\mathrm{HCl} 2 \mathrm{~N}$ & Terbentuk Busa Permanen & + \\
\hline Tanin & $\mathrm{FeCl}_{3}$ & $\begin{array}{l}\text { Terbentuk warna Biru tua } \\
\text { atau Hijau kehitaman }\end{array}$ & + \\
\hline
\end{tabular}

Dari tabel 1, dapat diketahui bahwa ekstrak etanolik daun kecombrang positif memiliki senyawa flavonoid, saponin, dan tanin. Hasil ini sama dengan hasil penelitian Kusumawati et al., (2015) yang menyatakan bahwaekstrak daun kecombrang mengandung flavonoid, saponin, tanin dan negatif alkaloid.

\section{Uji Aktivitas Antibakteri}

Uji aktivitas antibakteri ekstrak etanolik daun kecombrang terhadap Staphylococcus aureus dilakukan dengan menggunakan metode difusi. Hasil ekstrak dibuat dalam 4 konsentrasi yakni 25\%, 50\%, 75\% dan 100\%. Kontrol positif yang digunakan adalah kloramfenikol sedangkan kontrol negatif yang digunakan DMSO 2\%. Hasil uji aktivitas antibakteri dapat dilihat pada tabel 2 . 
Tabel 2 | Uji aktivitas antibakteri ekstrak etanolik daun kecombrang

\begin{tabular}{|c|c|c|c|c|c|}
\hline \multirow{2}{*}{\multicolumn{2}{|c|}{ Jenis }} & \multicolumn{3}{|c|}{ Diameter Zona Hambat (mm) } & \multirow{2}{*}{$\begin{array}{l}\text { Rata-rata } \\
\quad(\mathrm{mm})\end{array}$} \\
\hline & & Cawan 1 & Cawan 2 & Cawan 3 & \\
\hline \multirow{4}{*}{$\begin{array}{l}\text { Konsentrasi Ekstrak } \\
\text { Kecombrang }\end{array}$} & $25 \%$ & 12 & 15 & 11 & 12.67 \\
\hline & $50 \%$ & 15 & 15 & 13 & 14.33 \\
\hline & $75 \%$ & 14 & 15 & 17 & 15.33 \\
\hline & $100 \%$ & 17 & 16 & 18 & 17.00 \\
\hline \multirow{2}{*}{ Kontrol } & (+) Kloramfenikol & 15 & 15 & 15 & 15.00 \\
\hline & (-) DMSO 2\% & - & - & - & - \\
\hline
\end{tabular}

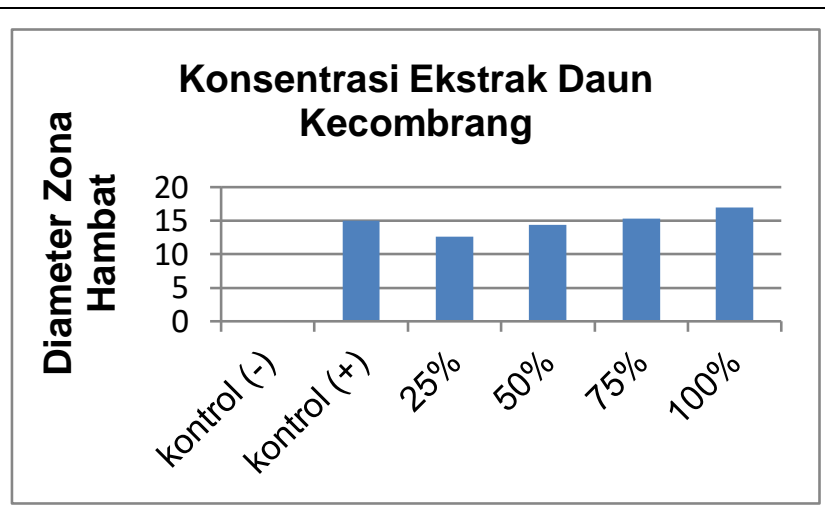

Gambar 1 | Grafik uji aktivitas antibakteri ekstrak etanolik daun kecombrang terhadap Staphylococcus aureus

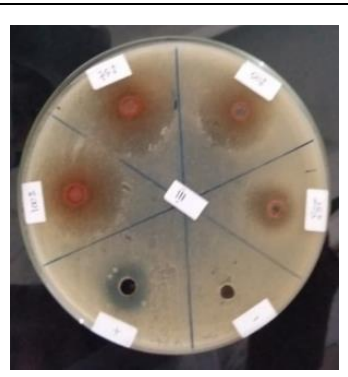

Gambar 2 | Hasil uji difusi ekstrak etanolik daun kecombrang terhadap Staphylococcus aureus

Hasil penelitian pada tabel 2, gambar 1 dan 2 menunjukkan bahwa ekstrak etanolik daun kecombrang dapat menghambat bakteri Staphylococcus aureus. Besarnya zona hambat berbeda-beda pada masing-masing konsentrasi, yaitu: konsentrasi $25 \%$ sebesar $12,67 \mathrm{~mm}$, konsentrasi $50 \%$ sebesar 14,33 $\mathrm{mm}$, konsentrasi $75 \%$ sebesar $15,33 \mathrm{~mm}$, dan pada konsentrasi $100 \%$ sebesar 17,00 $\mathrm{mm}$. Semakin besar kosentrasi ekstrak etanolik etanolik daun kecombrang yang diberikan pada bakteri maka semakin besar pula daya hambat dari ekstrak tersebut. Hasil penelitian ini sejalan dengan penelitian Silalahi (2019) yang menyatakan bahwa ekstrak daun kecombrang dapat menghambat pertumbuhan bakteri Streptococcus mutans dengan zona hambat 
terbesar dihasilkan pada ekstrak dengan konsentrasi 100\%. Kusumawati, et al., (2015) juga menyatakan bahwa ekstrak etanol daun kecombrang terhadap bakteri Salmonella typhi diperoleh kesimpulan bahwa semakin besar konsentrasi ekstrak etanol kecombrang, semakin besar pula zona hambat yang dihasilkan. Menurut Ningtyas (2010) keefektifan suatu zat antimikroba dalam menghambat pertumbuhan tergantung pada sifat mikroba uji, konsentrasi, dan lamanya waktu kontak.

Berdasarkan hasil penelitian, terbukti bahwa ekstrak daun kecombrang memiliki aktivitas sebagai antibakteri. Hal ini kemungkinan disebabkan oleh adanya senyawa aktif yang terdapat di dalam daun tersebut antara lain: flavonoid, saponin, dan tannin. Kandungan flavonoid yang terdapat di dalam ekstrak, dapat menimbulkan denaturasi protein yang terdapat pada dinding sel sehingga dapat merusak susunan dan merubah mekanisme permeabilitas dari mikrosom, lisosom dan dinding sel bakteri (Erianti et al, 2015). Saponin bersifat hidrofilik dan mampu menurunkan tegangan permukaan sehingga mengakibatkan naiknya permeabilitas atau kebocoran sel dan mengakibatkan senyawa intraseluler akan keluar yang akhirnya menyebabkan hancurnya bakteri (Nuria et al, 2009). Tanin mempunyai kemampuan sebagai antimikroba diduga karena tanin akan membentuk kompleks dengan enzim ekstraseluler yang dihasilkan oleh patogen atau dengan mengganggu proses metabolisme patogen tersebut (Cahyaningtyas et al., 2019).

Kontrol negatif yang digunakan adalah DMSO 2\%. DMSO 2\% digunakan untuk mengencerkan ekstrak daun kecombrang dan diuji aktivitas antibakterinya untuk mengetahui apakah DMSO $2 \%$ dapat menghambat pertumbuhan bakteri. Hasil penelitian menunjukkan bahwa DMSO $2 \%$ tidak memiliki aktivitas antibakteri yang dibuktikan tidak terbentuknya zona hambat. Penelitian ini menggunakan kloramfenikol (30 $\mu \mathrm{g})$ sebagai kontrol positif. Kloramfenikol merupakan salah satu antibiotik yang mempunyai spektrum kerja yang luas. dan dapat menghambat pertumbuhan bakteri gram positif maupun bakteri gram negatif dengan cara menghambat sintesa protein bakteri (Handayani, 2009). Berdasarkan hasil penelitian yang telah dilakukan, diperoleh zona hambat pada konsentrasi $75 \%$ dan $100 \%$ sebesar 15.33 dan $17.00 \mathrm{~mm}$, sedangkan pada kontrol positif kloramfenikol didapatkan zona hambat sebesar $15.00 \mathrm{~mm}$. Prescott dan Klein (2009) menjelaskan bahwa bakteri yang memiliki diameter zona hambat sebesar 13-17 $\mathrm{mm}$ termasuk kedalam kategori intermediet. Maka dapat disimpulkan bahwa ekstrak daun kecombrang $75 \%$ memiliki daya hambat antibakteri setara dengan kloramfenikol (30 $\mu \mathrm{g})$ dan konsentrasi $100 \%$ memiliki daya hambat lebih besar dari pada Kloramfenikol sebagai kontrol positif

Tabel 3 | Hasil Uji One Way Anova

\begin{tabular}{lccccc}
\hline Diameter Zona Hambat & & & & & \\
\hline & Sum of Squares & df & Mean Square & F & Sig. \\
\hline Between Groups & 29.733 & 4 & 7.433 & 4.130 & .031 \\
\hline Within Groups & 18.000 & 10 & 1.800 & & \\
\hline \multicolumn{1}{c}{ Total } & $\mathbf{4 7 . 7 3 3}$ & $\mathbf{1 4}$ & & & \\
\hline
\end{tabular}


Pengujian statistika menggunakan uji Anova satu arah (One Way Anova). Sebelumnya dilakukan pengujian Klomogorov-Smirnov untuk menguji normalitas data dan mensyaratkan data penelitian normal untuk uji Anova. Data dari tabel didapatkan hasil Asymp.Sig. sebesar 0,254 . Nilai ini $>0,05$ sehingga disimpulkan bahwa data dari penelitian terdistribusi normal. Pengujian selanjutnya adalah uji Levene Statistic yang didapatkan hasil sebesar 0,074 yang berarti bahwa data tersebut homogeny atau memiliki variasi yang sama. Berdasarkan Uji One Way Anova pada Tabel 3 menunjukkan bahwa uji tersebut memiliki signifikansi 0,031 yang berarti terdapat perbedaan bermakna dari hasil perlakuan pada daya hambat masing-masing konsentrasi ekstrak etanol daun Kecombrang. Hasil uji Post Hoc Student Neuman Keuls didapatkan bahwa konsentrasi $100 \%$ memiliki aktivitas antibakteri paling baik paa konsentrasi yang lainya.

\section{KESIMPULAN}

Berdasarkan hasil penelitian yang telah dilakukan dapat disimpulkan bahwa ekstrak etanolik daunkecombrang mempunyai aktivitas antibakteri terhadap Staphylococcus aureus. Konsentrasi ekstrak etanolik yang paling baik dalam menghambat Staphylococcus aureus adalah konsentrasi $100 \%$.

\section{DAFTAR PUSTAKA}

Agustin BA, Puspawaty N,
RM.2018. Akmana
Kombinasi Ekstrak Etanolik Daun
Beluntas (Pluchaea indica Less.) dan
Meniran (Phyllanthus niruri L.) terhadap
Bakteri Staphylococcus aureus.
Biomedika. 2018;11(2):79-87. DOI:

https://doi.org/10.31001/biomedika. v11i2.425

Amin, Z. L. 2014. Pemilihan Antibiotik yang Rasional.Medical Review.XXVII(3).

Cahyaningtyas D.M., Puspawati, N., Binugraheni, R. 2019. Uji Aktivitas Antibakteri Ekstrak Etanolik Kayu Secang (Caesalpinia sappan L.) terhadap Staphylococcus aureus. Jurnal Biomedika. 12 (2): 205-216. DOI: https://doi.org/10.31001/biomedika.v12i 2.614

Erianti, F., Marisa, D. dan Suharto, E. 2015. Potensi Antiinflamasi Jus Buah Belimbing (Averrhoa carambola L.) terhadap Denaturasi Protein In Vitro. Berkala Kedokteran, 11(1): 33-39.

Handayani, D. 2009. "Isolasi Senyawa Kimia Utama dan Uji Aktivitas Antibakteri dari Fraksi Etil Asetat Spon Laut Petrosia nigrans ". Skripsi. Fakultas Farmasi, Universitas Andalas, Padang.

Handoko, T. 1995. Farmakologi dan Terapi. Edisi Empat. Jakarta: Gaya Baru.

Koraag, M.E., Anastasia, H., Isnawati, R., Octaviani. 2016. Efikasi Ekstrak Daun dan Bunga Kecombrang (Etlingera elatior) terhadap Larva Aedes aegypti. Aspirator, 8(2), 63-68.

Kusumawati, E., Supriningrum, S., Rozadi, R.2015.Uji Aktivitas Antibakteri Ekstrak Etanol Daun Kecombrang Etlingera elatior (Jack) R. M. Sm terhadap Salmonella typhi. Jurnal IImiah Manuntung, 1(1), 1-7.

Naufalin, R. 2005. "Aktivitas Antibakteri Ekstrak Bunga Kecombrang (Nicolaia speciosa Horan) terhadap Berbagai Mikroba Patogen dan Perusak Pangan". Jurnal Teknologi dan Industri Pangan.16 (2).

Ningtyas, R. 2010. " Uji Antioksidan dan Antibakteri Ekstrak Air Daun Kecombrang (Etlingera elatior (Jack) 
R.M. Smith) ". Skripsi. Universitas Islam Negeri Syarif Hidayatullah, Jakarta.

Nuria, M.C., A. Faizatun A., dan Sumantri. 2009. Uji Antibakteri Ekstrak Etanol Daun Jarak Pagar (Jatropha cuircas L) terhadap Bakteri Staphylococcus aureus ATCC 25923, Escherichia coli ATCC 25922 dan Salmonella typhi TCC 1408.Jurnal Ilmu-ilmu Pertanian, 5(2); 26-37.

Presscott, H dan Klein. 2005. Microbiology Sixth Edition. Mc Graw Hill Higher Education.

Silalahi, S.Y.2019. Uji Aktivitas Antibakteri Ekstrak daun kecombrang (etlingera elatior) terhadap Streptococcus mutans. Skripsi. Medan. Fakultas Biologi. Universitas Medan Area. 